fellows tend to choose a laboratory and then apply for funds to work there, the most effective type of funding is the fellowship, which can be applied for as needed. The high level of competition for many European fellowships, such as the EU Marie Curie Fellowship scheme and the EMBO long-term fellowships, suggests that availability of funding is often a significant factor that influences decisions on where to work. It is worrying, therefore, to see that future plans for EU funding of biomedical science are directed towards large-scale projects instead of funding more postdoctoral fellowships within Europe. Fellowships that are specifically designed to promote a two-way exchange of postdoctoral personnel between European and US laboratories would also be beneficial.

Conditions of employment will also affect decisions on where to work. The days when postdoctoral researchers were prepared to work an 'apprenticeship' on low wages without benefits are almost certainly over. The postdoctoral scientists of today rightly regard themselves as highly qualified professionals and are fully aware of their value. Many have young families to provide for. If we wish to keep them in Europe, then it will be necessary to ensure that they are paid adequately wherever they are working. An arrangement that allowed pension benefits for scientists to be transferred between European countries would also be a major incentive to remain within the European research area. In addition, it is important that conditions for senior academic appointments that are designed to 'attract back' postdoctoral fellows from the USA do not end up discriminating against those who have stayed in Europe. This will only increase the problem by providing an additional incentive for postdoctoral researchers to leave the European system.

Changing perceptions may prove to be the most important task of all. There is a widespread view among European scientists that the most advantageous career path is to do one's postdoctoral work in the USA and then return to Europe to become a principal investigator. Since laboratories require both postdoctoral fellows and laboratory heads, the logical flaw in this view is obvious. If it were correct, it would also suggest that there is something seriously wrong with European science. In fact, an examination of the track record of European laboratories shows that they can provide a training environment which is every bit as good as that of their American counterparts. The injection of energy and ability that would come from retaining our best postdoctoral scientists can only further enhance the quality of science in Europe. It is time for
European laboratory heads to begin to convey that message to their graduate students when they are considering where to go for their postdoctoral training.

\section{References}

Breithaupt, H. (2000) The flight from European science. EMBO Rep., 1, 104-105.

Butler, D. (2000) Court young French postdocs, says petition. Nature, $\mathbf{4 0 8}, 126$.

Stone, R. (2000) New Program Supports Facilities, Stipends. Science, 289, 226-227.

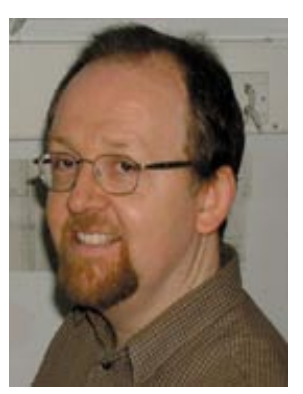

Niall Dillon is at the MRC Clinical Sciences Centre, Imperial College School of Medicine, London, UK.

E-mail: niall.dillon@csc.mrc.ac.uk

DOI: 10.1093/embo-reports/kve190

\title{
Science and ethics
}

\section{As research and technology are changing society and the way we live, scientists can no longer claim that science is neutral but must consider the ethical and social aspects of their work $\bullet$ by Maurizio Iaccarino}

Less than 500 years ago, science was a dangerous business. In 1600, the Italian monk Giordano Bruno was sentenced to death and burned at the stake because he believed in free thinking in philosophy and science. Galileo Galilei narrowly avoided the same fate but only by publicly renouncing his support of Copernicus' heliocentric view. Of course, the days of autodafés are over and modern science has an important influence on the development of society as a whole,

compared with the days of the ill-fated Bruno. But while scientific progress has been rapid and astonishing, it is still dis-

application of science in new technologies and products. Furthermore, as scientific progress becomes increasingly

As scientific progress becomes increasingly fundamental to society, it is constantly challenging, if not completely clashing with, long-held beliefs concerning our ethical values

turbing for those people who feel excluded from the debate surrounding the fundamental to society, it is constantly challenging if not completely clashing 


\section{viewpoint}

with long-held beliefs concerning our ethical values. It is, therefore, necessary to conduct ethical discussions in order to adapt the use of scientific knowledgenamely new forms of technology-to a general context that is in agreement with the basic principles of our civilisation. Scientists should be concerned about the use of scientific knowledge and they should address the ensuing ethical questions, both in general terms and in terms of their own work.

The word 'ethics' comes from the Greek word 'ethos', meaning custom or behaviour. The concept of ethics was originally proposed by the Greek philosopher Aristotle for the discussion of philosophical questions relating to daily life: the 'ethike theoria' deals with the study of, and gives criteria for the evaluation of human behaviour. Since then, ethics has become one of the major topics in Western philosophy when debating social and individual values, their relationship

\section{Scientific progress requires a critical mind, free of prejudice and open to new ways of thinking}

and their hierarchy in society. Today, the meaning of 'ethics' is more or less equivalent to that of 'morals', which comes from the Latin word 'mos, moris' and also means custom or behaviour, but at a more personal level. Moralists, such as Nietzsche, Santayana and Russell, claim that ethical values are rather personal interpretations, deliberations or preferences and not general principles that can be proven true or false. John Ziman, the former Chairman of the Council for Science and Society, interprets ethics not as an abstract discipline but as a way of dealing with differing opinions that arise when traditional values are faced with new realities (Ziman, 2001).

Indeed, discussions about the ethical foundations of a society and their reinterpretation usually take place when traditional customs or behaviours are challenged by new developments. In a static society, values are well codified, usually by religion or by tradition. This is true for numerous ancient societies, which remained unchanged for centuries. But wars, invasions or a new culture or religion usually prompt the evaluation of the traditional values. For instance, the French and Russian revolutions in Europe as well as colonialism on other continents effectively upset and irrevocably changed society's traditional values to varying degrees. Later in the $20^{\text {th }}$ century, the creation of new technologies through scientific progress had a profound effect on society, public opinion and our way of life and has thus sparked discussion on how to use this knowledge (http://www.pugwash.org/). In the 1950s and 1960s, ethical discussions ours. They proclaimed the neutrality of science, stating that the advancement of knowledge could not be considered good or bad. In this context, science was not responsible for its applications, and even less for their subsequent use.

Industrial research, on the other hand, was radically different. Although based on the same knowledge, it had completely different aims and rules. Results were not owned by scientists, but were the property of the industries financing the research. The aim was not to acquire

Scientists proclaimed the neutrality of science, stating that the advancement of knowledge could not be considered good or bad

dealt mainly with the use of physics and engineering for the construction of new weapons (http://www.lasg.org/pledge/ pledgefrm_a.html). In the 1970s and 1980s, the focus was on environmental problems. Today, most ethical discussions deal with the progress in biology and its consequences for society.

Scientific progress, the driving force for the majority of the changes witnessed in the $20^{\text {th }}$ century, requires a critical mind, free of prejudice and open to new ways of thinking. The rapid development of modern science since the Renaissance is due mainly to the postulate that scientific theories should be independent of theological or religious beliefs. In the $17^{\text {th }}$ and $18^{\text {th }}$ century, knowledge was mainly exchanged through scientific academies which disseminated new theories and thus new knowledge, but to invent new products in order to increase profits. Ethical problems were considered to be the responsibility of the company and not of the scientists.

As a result, discussions concerning ethical problems were more or less absent from both realms. In academia, scientists were indifferent to the possible consequences of their work and in industry, employers did not consider it appropriate for scientists to worry about ethical problems. Of course, this description of academic and industrial research is schematic and does not truly represent the real world. Nevertheless, it still exists and sways the minds of those who have the greatest influence on our contemporary scientific culture.

Since the 1950s, large changes in the

\section{World Conference on Science}

Science Agenda-Framework for Action, Chapter 3.2 Ethical issues

71. Ethics should be part of the education and training of all scientists.

72. Research institutions should foster the study of ethical aspects of scientific work.

73. The international scientific community should promote environmental ethics.

74. Scientific institutions should comply with ethical norms.

75. Governments and civil society should organise debates on the ethical implications of scientific work.

76. Governments and civil society should set up ethics committees.

77. UNESCO should strengthen its Bioethics Committee and the World Commission on the Ethics of Scientific Knowledge and Technology. http://www.unesco.org/science/wcs/eng/ key_documents.htm

accelerated scientific progress. At the beginning of the $19^{\text {th }}$ century, there was a remarkable rise in academic research at universities, also labelled 'pure' research. Scientists were not interested in practicalities and were not concerned with the technological applications of the results of their endeav- interactions between academic and industrial research have taken place, even in their definition, and ample literature exists on this subject. Scientists in academia receive more financing than in the past. Furthermore, science administrators usually make decisions on the basis of 


\section{viewpoint}

social considerations, namely on the expected contribution to problems such as health, food, energy, etc. Such research policies have an ethical component as they aim to solve social problems. As a consequence, it has become pertinent and necessary to evaluate, from an ethical point of view, not only the use of scientific knowledge, but also its production. Industrial research, on the other hand, has become more sophisticated and its results are often published in peer-reviewed journals. Furthermore, scientists in academia and industry are increasingly collaborating, and this is even encouraged in most countries.

The relationship between public and private research is the source of further ethical issues, which are important not only for the research community, but for all sectors of society. Universities and public research institutes encourage their scientists to request funds from industry and to patent their results. Scientists working in the public sector increasingly own patents or shares, or act as consultants for companies (http://www.cspinet.org/integrity/database.html). These activities are an important source of income as well as expertise and proprietary technology for the universities. Moreover, they are encouraged by politicians since they generate start-up companies and

\section{Conflicts of interest}

The possibility of using the resources of public institutions for private interests;

Undue influence by the private sector on the establishment of priorities of public research;

Differences of opinion in the use of public structures between scientists having industrial

collaborations and scientists receiving only public funds;

Worry among graduate students that their advisor may serve industrial interests and not

educational ones;

Difficulties in finding experts free of conflicts of interest.

stimulate local economies. Although this phenomenon is considered to be very useful, it can and already has caused conflicts of interest (Cech, 2001; sidebar). There are worries that, especially in clinical research, the conflicts of interest have become so pervasive (Smaglik, 2000) and so difficult to disclose (Holden, 2001; Knight, 2001) that the rate of approval of new drugs will soon begin to diminish (Wadman, 2001).

As an example of the necessity of conducting discussions on ethics, I wish to refer to the debate on embryonic stem cells (Lachmann, 2001; http://bioethics.gov/ stemcell_exec_intro.htm). Knowledge concerning human stem cells could be used cords of newborn infants. However, results could possibly be achieved in a shorter time-frame using embryonic cells, and, moreover, it is not yet clear whether adult cells have the same potential to differentiate into various tissues.

I am convinced that this topic is so sensitive because society does not have an informed opinion and therefore still has to find a consensus. Again, this is a question of hierarchy of values: is the life of a frozen embryo more important than a cure for a disease? A moratorium to suspend research using human embryonic cells must include both the public and private domains since to allow the latter to continue would be true hypocrisy. Of course, no restriction should be imposed on research using adult stem cells or embryonic stem cells isolated from animals. But I think it would be difficult to establish such a moratorium for several reasons. First, it should be respected all

Solutions to ethical problems that come from scientific progress cannot be imposed by dogma of faith, or by law.

'dopaminergic' neurons for the treatment for the treatment of diabetes. This is ch strategy and not a working techwill be achieved easily, since the implanof new cells in an organism may metabolic circuits. However, the public debate asks if it is ethical to destroy knowledge for the purpose of gain diseases (Science, 2000). The arguments tially deal with the respect for human life or human dignity (Mieth, 2000). suspend research with embryonic stem cells and prefer instead the use of adult stem cells or blood cells from the umbilical

to devise new therapies that may benefit
millions of patients (Vogel, 2001). These differentiated in vitro to produce specific cell lines, which could be used as cell reasons. First, it should be respected all . 


\section{viewpoint}

generating new technologies that are causing ethical problems. But scientific knowledge alone can create ethical problems of its own. In the case of abortion, new insights into embryo development have given fresh arguments to those who want to see abortion banned. In fact, in the past, the embryo and the fertilised egg were considered to be without life or without soul, while today we know much more about their potential. Indeed, it is becoming increasingly necessary for scientists to devote more attention to ethical problems concerning their research and resulting new technologies (Rotblat, 1999a,b). Everybody should be involved, because the solutions to ethical problems that come from scientific progress cannot be imposed by dogma of faith, or by law. It is the civil society, which includes scientists, that must find an acceptable solution. Only then can governments react and draft new laws to address these problems (see also the Center for Applied and Professional Ethics: http://cape. cmsu.edu).

Unfortunately, such a commitment to debate ethical challenges is insufficient at all levels of society and within the scientific community. Furthermore, the conflicts of interest I mentioned above complicate the issue. It is therefore important that governments, public and private funding organisations, scientific societies and the researchers themselves become more sensitive to ethical questions. In the present climate, upholding the neutrality of science would not be amoral, but immoral. Scientists are the first to receive crucial information, sometimes years in advance, about the potential dangers of certain scientific knowledge. I refer, for example, to Niels Bohr and the atomic bomb, to Paul Berg and genetic engineering or to lan Wilmut and cloning. Thus, the onus is on the scientists to inform the public about the potential dangers of new technologies and to engage the public in debates on how to use their knowledge wisely and in the best public interest (laccarino, 2001).

What are the most important ethical implications of scientific research and the development of new technologies? In 1999, UNESCO and ICSU organised a World Conference on Science, for governments to discuss problems regarding science and society. They eventually approved a document, the 'Science
Agenda-Framework for Action', that contains a chapter on ethical issues. As this document was approved following thorough consultation with all UNESCO member states and informed discussion with their respective scientific communities, it can be considered a useful reference to identify and deal with ethical problems that stem from scientific research in a general context. Here, I report a summary, in my words, of each paragraph (see sidebar). Obviously, it is necessary to consult the original text for the simple reason that each word was approved after long discussion (http://www.unesco.org/ science/wcs/eng/framework.htm).

And how can we make the scientists more sensitive to the ethical implications of their work? I think it is necessary to start from the bottom, namely at the level of individual scientists. The most appropriate context to discuss ethical questions is the annual meetings of scientific societies (Smaglik and Macilwain, 2001). I suggest that participants are asked to propose and discuss ethical commitments, and to decide whether it is necessary to make them obligatory for all members of that particular scientific society. Of course, it is also necessary to invite members of the public, or even critics, in order to appreciate their perceptions and expectations of scientific research. Only in this way can we understand what are the most sensitive issues for researchers and make them more aware of the ethical implications of their work. Researchers, who are often university professors, would then be more prepared to inform their students about ethical problems. Subsequently, it will be possible to come to a more general conclusion at a national, or even better, at an international level. The ethics of science is not a personal problem but a collective problem that involves all scientists at a personal but also at a general level.

We live in a world in which scientific knowledge and new technologies continuously challenge our values. We all have to live our daily lives and make decisions based on the fundamental values of human dignity embedded in our civilisation. Scientists are no exception. Rather, I am convinced that they have an obligation to make a special effort to contribute to this discussion, because they often have more information and more basic knowledge about the very issues that generate these ethical dilemmas.

\section{References}

Cech, T.R. (2001) Conflicts of interest-moving beyond disclosure. Science, 291, 989.

Flothmann, S. and van Aken, J. (2001) Of maize and men. EMBO Rep., 2, 644-647.

Holden, C. (2001) Few authors disclose conflicts, survey finds. Science, 292, 829.

Iaccarino, M. (2001) About the precautionary principle. EMBO Rep., 1, 454-456.

Knight, J. (2001) Study says authors are averse to declaring conflicts of interest. Nature, 411, $828-829$.

Lachmann, P. (2001) Stem cell research-why is it regarded as a threat? EMBO Rep., 2, 165-168.

Leaver, C.J. and Trewavas, A.J. (2001) Is opposition to GM crops science or politics? EMBO Rep., 2, 455-459.

Lenoir, N. (1996) The ethics of science: between humanism and modernity. UNESCO World Science Report, pp. 204-213.

Mieth, D. (2000) Going to the roots of the stem cell debate. EMBO Rep., 1, 4-6.

Rotblat, J. (1999a). Science and human values. Proceedings of the World Conference on Science in Budapest, pp. 45-49. http:// www.unesco.org/science/wcs/index.htm

Rotblat, J. (1999b). A Hippocratic Oath for scientists. Science, 286, 1475

Science (2000) 287, 1417-1426.

Smaglik, P. (2000) US regulation threat over business links... Nature, 406, 817.

Smaglik, P. and Macilwain, C. (2001) Scientists seek solidarity in oaths. Nature 409, 971.

Vogel, G. (2001). Nobel laureates lobby for stem cells. Science, 291, 1683-1684.

Wadman, M. (2001) Fear of bias puts spotlight on drug approval. Nature, 411, 981.

Ziman, J. (2001) Getting scientists to think about what they are doing. Sci. Engl. Ethics, 7, 165-176.

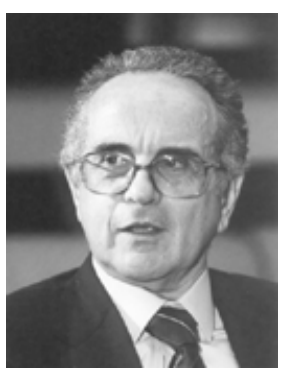

Maurizio Iaccarino is the Secretary General of the UNESCO-ICSU World Conference on Science and presently works at the International Institute of Genetics and Biophysics of the CNR in Naples, Italy. The author wishes to thank L. Pica and G. Ventrella for useful discussions.

E-mail: accarin@iigb.na.cnr.it

DOI: $10.1093 /$ embo-reports/kve191 